\title{
Hubungan Kadar Vitamin C Plasma dengan Serangan Asma pada Anak
}

\author{
Azwar Aruf, Roni Naning, Mei Neni Sitaresmi \\ Bagian Ilmu Kesehatan Anak Fakultas Kedokteran Universitas Gadjah Mada/RSUP Dr. Sardjito, \\ Yogyakarta
}

\begin{abstract}
Latar belakang. Banyak faktor yang dapat memicu serangan asma. Perhatian terhadap peran nutrisi antioksidan serta stres oksidatif pada kejadian asma beberapa tahun terakhir ini semakin meningkat. Beberapa penelitian melaporkan bahwa kadar vitamin C plasma yang rendah merupakan faktor risiko serangan asma, meskipun masih kontroversial. Belum ada penelitian mengenai vitamin $\mathrm{C}$ plasma dan asma di Indonesia. Tujuan. Menilai apakah kadar vitamin C plasma rendah merupakan faktor risiko serangan asma pada anak, dengan cara membandingkan kadar vitamin C plasma anak asma dalam serangan dan anak asma tidak dalam serangan.

Metode. Desain penelitian ini adalah penelitian kasus kontrol. Pengambilan sampel dilakukan secara konsekutif. Subyek adalah semua anak yang terdiagnosis asma dalam serangan dan tidak dalam serangan di RSUPDR. Sardjito Yogyakarta sejak April 2012 sampai dengan Agustus 2013. Subyek dibagi menjadi dua kelompok, 39 anak kelompok asma tidak dalam serangan dan 39 anak kelompok asma dalam serangan. Kadar vitamin C plasma diperiksa dengan metode kuantitatif spektofotometer.

Hasil. Karakteristik subyek, antara lain umur, jenis kelamin, riwayat kontak hewan peliharaan, riwayat kontak tungau debu rumah, perokok pasif, alergi makanan, infeksi saluran pernapasan, kadar vitamin C plasma. Analisis bivariat dilakukan dengan uji kemaknaan (nilai p<0,05), dan rasio Odds. Kadar vitamin C plasma kelompok asma dalam serangan dan tidak dalam serangan tidak berbeda bermakna dengan nilai $\mathrm{p}=0,77$ dan rasio Odds 1,18 (IK95\%: 0,32;3,64). Infeksi pernapasan merupakan faktor risiko serangan asma yang bermakna dengan nilai p=0,006 dan rasio Odds 3,6 (IK 95\% 1,41;9,19). Sari Pediatri 2014;16(2):91-6.
\end{abstract}

Kata kunci: vitamin C plasma, serangan asma

revalensi asma di dunia diperkirakan $7,2 \%$ (6\% pada dewasa dan $10 \%$ pada anak), diperkirakan 300 juta orang di dunia menderita asma. Penelitian Kartasasmita

\section{Alamat korespondensi:}

dr. Azwar Aruf, Jl. Pandega Marta No. 344 Pogung Lor, Sleman, Yogyakarta. Telp: 081328710811. E-mail:aza_ruf@yahoo.com tahun 2002 menyatakan bahwa prevalensi asma pada anak di Indonesia adalah 5,2\%. ${ }^{1-3}$

Perhatian terhadap peran nutrisi antioksidan serta stres oksidatif pada kejadian asma beberapatahun terakhir ini semakin meningkat. Asupan makanan, terutama vitamin A, C, E, dan karotinoid dikatakan memiliki hubungan dengan kejadian dan derajat asma. $^{4}$ 
Penelitian epidemiologi dan survei populasi di Inggris, Amerika Serikat, Belanda, dan Cina ditemukan bahwa rendahnya asupan vitamin $\mathrm{C}$ juga berhubungan dengan peningkatan reaktivitas bronkial, gejala mengi pada remaja dan anak-anak. ${ }^{5}$ Beberapa penelitian berbasis populasi mendukung hal ini, bahwa sebagian besar penelitian melaporkan hubungan positif antara fungsi paru dan vitamin antioksidan. Sebagian besar penulis mengukur kadar antioksidan serum atau melakukan penilaian asupan makanan. ${ }^{6,7}$

Penelitian kasus kontrol Hijazi $\mathrm{dkk}^{8}$ pada anak asma umur 12 tahun dilaporkan tidak ada hubungan vitamin $\mathrm{C}$ dengan kejadian asma. Penelitian Powel $\mathrm{dkk}^{9}$ juga melaporkan bahwa rendahnya kadar vitamin C plasma pada kasus asma tidak berbeda bermakna dengan anak yang bukan kasus asma.

Penelitian yang menilai peran vitamin C, terutama peran kadar vitamin $\mathrm{C}$ plasma pada serangan asma masih terbatas, terutama di Indonesia. Penelitian ini dilakukan bertujuan untuk menilai hubungan antara kadar vitamin $\mathrm{C}$ plasma dengan kejadian serangan asma pada anak.

\section{Metode}

Penelitian kasus kontrol ini dilakukan di RSUP Dr. Sardjito Yogyakarta sejak 1 April 2012-31 Agustus 2013 dengan populasi terjangkau semua anak penderita asma. Pengumpulan sampel dilakukan dengan cara konsekutif. Anak asma dikelompokkan menjadi kelompok asma tidak dalam serangan dan kelompok asma dalam serangan, masing-masing kelompok 39 orang. Kriteria inklusi adalah pasien anak yang terdiagnosis asma oleh dokter di bagian anak/ Instalasi Kesehatan Anak (INSKA) RSUP DR.Sardjito Yogyakarta dan orangtua pasien bersedia secara tertulis mengikuti prosedur penelitian. Kriteria eksklusi antara lain gizi buruk, menderita penyakit jantung bawaan, gagal jantung, penyakit paru selain asma (penyakit paru obstruktif kronis, emfisema, bronkiektasis, tuberkulosis paru).

Kedua kelompok diukur kadar vitamin C plasmanya dengan cara pengambilan sampel darah beku 3-5 cc dalam tabung plasma heparin dan kemudian diperiksa di laboratorium biokimia Fakultas Kedokteran Universitas Gadjah Mada Yogyakarta dengan metode spektrofotometer kuantitatif. Kadar vitamin C plasma dinyatakan dengan kadar vitamin $\mathrm{C}$ plasma rendah apabila $<0,4 \mathrm{mg} / \mathrm{dL}$ dan tidak rendah apabila $\geq 0,4$ $\mathrm{mg} / \mathrm{dL} .{ }^{10}$ Data mengenai faktor risiko serangan asma lainnya dikumpulkan dengan kuesioner. Analisis bivariat kadar vitamin $\mathrm{C}$ plasma dan faktor risiko serangan asma lainnya dilakukan dengan chi square, Kolmogorov-smirnov, uji Fisher. Analisis multivariat dilakukan dengan regresi logistik.

Penelitian ini dilakukan dengan persetujuan Komite Etik Fakultas Kedokteran Universitas Gadjah Mada Yogyakarta. Pasien memberikan informed consent secara sukarela untuk pengambilan sampel darah vena untuk pemeriksaan kadar vitamin C plasma.

\section{Hasil}

Selama periode penelitian didapatkan 78 subyek. Sebanyak 39 anak sebagai kelompok asma dalam serangan dan 39 anak sebagai kelompok asma tidak dalam serangan. Tujuh puluh delapan anak terdiri dari 48 anak laki-laki $(61,5 \%)$ dan 30 anak perempuan $(38,5 \%)$. Rerata usia pada kelompok asma dalam serangan 6,15 tahun dan pada kelompok asma tidak serangan 6,43 tahun.

Pada tabel karakteristik dasar, tidak terdapat perbedaan bermakna pada karakteristik umur, jenis kelamin, riwayat kontak dengan hewan peliharaan, riwayat kontak dengan tungau debu rumah, pajanan asap rokok, dan alergi makanan. Karakteristik yang berbeda bermakna terdapat pada infeksi saluran pernapasan (Tabel 1).

Kadar vitamin $\mathrm{C}$ rendah didapatkan pada 8 anak kelompok asma dalam serangan (20,5\%) dan 7 anak kelompok asma tidak dalam serangan (17,9\%). Kadar vitamin $\mathrm{C}$ pada kedua kelompok tidak menunjukkan perbedaan bermakna $(\mathrm{p}=0,77)$.

Risiko terjadinya serangan asma pada anak dengan kadar vitamin C plasma rendah adalah 1,18 (IK 95\% 0,$38 ; 3,64$ ) (Tabel 2). Hal tersebut menunjukkan bahwa vitamin $\mathrm{C}$ yang rendah tidak berhubungan dengan kejadian serangan asma.

Kadar vitamin C plasma juga tidak menunjukkan perbedaan bermakna terhadap derajat serangan asma. Analisis chi square untuk kadar vitamin C terhadap derajat serangan asma tidak memenuhi syarat sehingga dilakukan analisis dengan uji Kolmogorov-Smirnov dengan hasil $p=0,98$ dan uji Fisher setelah dilakukan pengelompokan derajat serangan menjadi serangan berat-sedang dibandingkan dengan serangan ringan 
juga tidak menunjukkan perbedaan yang bermakna dengan nilai $\mathrm{p}=0,10$.

Hasil penelitian ini menunjukkan bahwa kadar vitamin $\mathrm{C}$ tidak berhubungan dengan derajat serangan asma. Penelitian Misso dkk mengatakan bahwa kadar vitamin $\mathrm{C}$ plasma lebih rendah pada serangan asma derajat berat dengan rasio Odds 0,93; 95\% CI: 0,9 $-0,97$.
Penelitian ini menunjukkan bahwa terdapat perbedaan bermakna mengenai infeksi saluran pernapasan pada kelompok asma serangan dan tidak serangan. Duapuluh tujuh anak menderita infeksi saluran pernapasan pada kelompok serangan asma $(69,2 \%)$ dan 15 anak menderita infeksi saluran pernapasan pada kelompok asma tidak dalam serangan $(38,5 \%)$ dengan nilai kemaknaan $\mathrm{p}=0,006$.

Tabel 1. Karakteristik dasar subyek penelitian

\begin{tabular}{|c|c|c|c|c|}
\hline Karakteristik & n (\%) & $\begin{array}{c}\text { Asma serangan } \\
\mathrm{n}=39(\%)\end{array}$ & $\begin{array}{c}\text { Asma tidak serangan } \\
\mathrm{n}=39(\%)\end{array}$ & $\mathrm{p}$ \\
\hline Rerata umur & & $6,15 \pm 3,32$ & $6,43 \pm 3,45$ & \\
\hline Median umur & & 6,00 & 6,00 & \\
\hline \multicolumn{5}{|l|}{ Jenis kelamin } \\
\hline Perempuan & $30(38,5)$ & $13(33,3)$ & $17(43,6)$ & 0,35 \\
\hline Laki-laki & $48(61,5)$ & $26(66,7)$ & $22(56,4)$ & \\
\hline \multicolumn{5}{|l|}{ Kontak hewan } \\
\hline Ya & $31(39,7)$ & $13(33,3)$ & $18(46,2)$ & 0,25 \\
\hline Tidak & $47(60,3)$ & $26(66,7)$ & $21(53,8)$ & \\
\hline \multicolumn{5}{|c|}{ Kontak Tungau Debu Rumah } \\
\hline Ya & $32(41)$ & $15(38,5)$ & $17(48,7)$ & 0,64 \\
\hline Tidak & $46(59)$ & $24(61,5)$ & $22(51,3)$ & \\
\hline \multicolumn{5}{|l|}{ Perokok pasif } \\
\hline Ya & $36(46,2)$ & $19(48,7)$ & $17(43,6)$ & 0,65 \\
\hline Tidak & $42(53,8)$ & $20(51,3)$ & $22(56,4)$ & \\
\hline \multicolumn{5}{|l|}{ Alergi makanan } \\
\hline Ya & $13(16,7)$ & $7(17,9)$ & $6(15,4)$ & 0,76 \\
\hline Tidak & $65(83,3)$ & $32(82,1)$ & $33(84,6)$ & \\
\hline \multicolumn{5}{|c|}{ Infeksi saluran pernapasan } \\
\hline Ya & $42(53,8)$ & $27(69,2)$ & $15(38,5)$ & 0,006 \\
\hline Tidak & $36(46,2)$ & $12(30,8)$ & $24(61,5)$ & \\
\hline \multicolumn{5}{|c|}{ Kadar vitamin C plasma } \\
\hline Rendah & $15(19,2)$ & $8(20,5)$ & $7(17,9)$ & 0,77 \\
\hline Tidak rendah & $63(80,8)$ & $31(79,5)$ & $32(82,1)$ & \\
\hline
\end{tabular}

Tabel 2. Hubungan kadar vitamin C plasma dan infeksi saluran pernapasan terhadap serangan asma

\begin{tabular}{lcccc}
\hline & $\begin{array}{c}\text { Asma serangan } \\
\mathrm{n}=39(\%)\end{array}$ & $\begin{array}{c}\text { Asma tidak serangan } \\
\mathrm{n}=39(\%)\end{array}$ & Rasio Odds & $\mathrm{p}$ \\
\hline Kadar vitamin C & $8(20,5)$ & $7(17,9)$ & 1,18 & 0,77 \\
$\quad$ Rendah & $31(79,5)$ & $32(82,1)$ & $95 \%$ CI: $0,32-3,64$ & \\
Normal & & & 3,6 & 0,006 \\
Infeksi saluran pernapasan & $27(69,2)$ & $15(38,5)$ & & \\
$\quad$ Ya & $12(30,8)$ & $24(61,5)$ & $95 \%$ CI: $1,41-9,19$ & \\
$\quad$ Tidak & & & & \\
&
\end{tabular}


Rasio Odds infeksi saluran pernapasan terhadap serangan asma anak didapatkan 3,6 dengan IK95\% 1,41; 9,19 (Tabel 2). Hal tersebut menunjukkan bahwa anak dengan infeksi saluran pernapasan memiliki risiko 3,6 kali akan mengalami serangan asma dibandingkan dengan anak asma yang tidak menderita infeksi saluran pernapasan.

Beberapa penelitian juga mengaitkan hubungan antara infeksi saluran pernapasan dengan kadar vitamin $\mathrm{C}$ yang rendah. Hasil analisis tidak menunjukkan perbedaan bermakana antara kadar vitamin $\mathrm{C}$ subyek yang menderita infeksi saluran pernapasan dengan subyek yang tidak menderita infeksi saluran pernapasan $(\mathrm{p}=0,96)$ (Tabel 3).

Hasil penelitian ini menunjukkan bahwa tidak terdapat perbedaan bermakna faktor risiko pajanan asap rokok pada kelompok asma serangan dan tidak serangan dengan nilai $p=0,33$. Pajanan asap rokok pada penelitian ini dinilai hanya pada lingkungan di dalam rumah, sedangkan pajanan di luar rumah sulit dihindari. Hal tersebut dapat menyebabkan tidak terdapat perbedaan antara kedua kelompok.

Hatch $^{11}$ mengatakan bahwa pajanan asap rokok sendiri dapat menurunkan kadar vitamin C. Kami memandang perlu dilakukan analisis terhadap hal tersebut. Hasil analisis menunjukkan tidak ada perbedaan bermakna kadar vitamin C pada subyek terpapar asap rokok dan subyek yang tidak terpapar asap rokok dengan nilai kemaknaan $\mathrm{p}=0,23$ (Tabel $3)$.

Alergi makanan juga tidak menunjukkan perbedaan bermakna antara kelompok anak asma dalam serangan dan tidak serangan $(\mathrm{p}=0,76)$. Paparan terhadap alergen hirupan dalam rumah seperti alergen hewan peliharaan, alergen tungau debu rumah, pada penelitian ini juga tidak menunjukkan perbedaan bermakna antara kelompok anak asma dalam serangan dan tidak serangan $(\mathrm{p}=0,25$ dan $\mathrm{p}=0,64)$.

Kriteria variabel untuk bisa diikutkan dalam analisis regresi multivariat yaitu apabila pada analisis bivariat dihasilkan data $\mathrm{p}<0,25$ atau hasil analisis bivariat $p>0,25$. Namun, variabel tersebut mempunyai substansi yang penting pada prognosis asma. ${ }^{13}$ Hasil analisis bivariat hanya menunjukkan satu variabel yaitu infeksi saluran pernafasan yang memiliki nilai $\mathrm{p}<0,25$. Walaupun demikian, peneliti tetap melakukan analisis regresi untuk melihat peran masing-masing variabel dalam terjadinya serangan asma.

Tabel 3. Hubungan infeksi saluran pernapasan dan analisis paparan asap rokok terhadap kadar vitamin C

\begin{tabular}{lcccc}
\hline & $\begin{array}{c}\text { Vitamin C rendah } \\
\mathrm{n}=39(\%)\end{array}$ & $\begin{array}{c}\text { Vitamin C tidak rendah } \\
\mathrm{n}=39(\%)\end{array}$ & Rasio Odds & $\mathrm{p}$ \\
\hline Infeksi saluran pernapasan & $8(19)$ & $34(81)$ & 0,97 & 0,96 \\
$\quad$ Ya & $7(19,4)$ & $29(80,6)$ & $95 \%$ CI: $0,31-3,01$ & \\
Tidak & & & 2,00 & 0,23 \\
Paparan asap rokok & $9(25)$ & $27(75)$ & & \\
$\quad$ Ya & $6(14,3)$ & $36(85,7)$ & $95 \%$ CI: $0,63-6,29$ & \\
Tidak & & & & \\
\end{tabular}

IK95\%: interval kepercayaan 95\%

Tabel 4. Analisis regresi logistik

\begin{tabular}{lccc}
\hline Variabel & OR & CI & $\mathrm{p}$ \\
\hline Jenis kelamin & 0,47 & $0,15-1,42$ & 0,18 \\
Kadar vitamin C & 1,14 & $0,32-4,03$ & 0,83 \\
Kontak hewan peliharaan & 0,39 & $0,08-1,81$ & 0,23 \\
Kontak tungau debu rumah & 1,35 & $0,29-6,29$ & 0,70 \\
Infeksi saluran pernafasan & 4,91 & $1,73-13,09$ & 0,003 \\
Paparan asap rokok & 1,69 & $0,58-4,92$ & 0,33 \\
Alergi makanan & 1,48 & $0,40-5,46$ & 0,55 \\
\hline
\end{tabular}


Hasil akhir dari analisis regresi multivariat juga menunjukkan hanya variabel infeksi saluran pernapasan yang memiliki hasil bermakna. Variabel yang lain dikeluarkan karena nilai $p>0,05$. Kadar vitamin $\mathrm{C}$ merupakan variabel paling awal dikeluarkan dari pemodelan multivariat dengan nilai $\mathrm{p}=0,83$ (Tabel 6). Hal tersebut menunjukkan kadar vitamin $C$ yang rendah bukan merupakan faktor risiko terjadinya serangan asma pada anak.

\section{Pembahasan}

Hasil penelitian ini menunjukkan bahwa kadar vitamin $\mathrm{C}$ tidak berhubungan dengan serangan asma dan derajat serangan asma. Penelitian Misso $\mathrm{dkk}^{5}$ mengatakan bahwa kadar vitamin $\mathrm{C}$ plasma lebih rendah pada serangan asma derajat berat dengan rasio odd 0,93 (IK95\% 0,9;0,97). Perbedaan tersebut mungkin disebabkan karena pencetus serangan asma yang multifaktor dan subyek yang menderita asma berat hanya 2 orang dari kelompok serangan asma pada penelitian ini.

Perbedaan juga dapat disebabkan karena mekanisme untuk terjadinya serangan asma berbeda, antara lain proses inflamasi jalan napas, hiper-responsif bronkial, perubahan struktur jalan napas (airway remodeling). ${ }^{13}$ Proses inflamasi melibatkan banyak mediator inflamasi sedangkan vitamin $\mathrm{C}$ lebih banyak beperan sebagai antioksidan pada saluran napas dalam menghadapi oksidan endogen maupun eksogen yang menyebabkan stress oksidatif serta mengahambat prostaglandin. ${ }^{14}$

Asma merupakan penyakit yang kompleks melibatkan sistem autonom, imunologi, infeksi, sistem endokrin dan faktor psikologis yang berbeda derajatnya pada setiap individu. Salah satu mekanisme terjadinya seranngan asma disebabkan oleh oksidan pada lingkungan. Pasien asma mengalami peningkatan stres oksidatif yang diduga disebabkan oleh oksigen reaktif dan senyawa nitrogen. Oksigen reaktif dapat memicu produksi sitokin dan kemokin yang dapat menyebabkan eksaserbasi asma. Vitamin C berperan sebagai antioksidan yang melindungi epitel dan sel imun saluran pernapasan dari oksidan. ${ }^{15}$

Peranan vitamin $\mathrm{C}$ lebih banyak sebagai proteksi terhadap alergen polutan udara seperti nitrit dioksida, ozon yang merupakan oksidan yang dapat memicu serangan asma. Penelitian ini tidak mengukur alergen polutan udara luar rumah. Karena banyaknya mekanisme penyebab serangan asma dengan berbagai macam mediatornya, hal ini mungkin menyebabkan tidak tampaknya peran vitamin C sebagai faktor risiko serangan asma.

Hasil mengenai hubungan infeksi saluran pernapasan dengan serangan asma pada penelitian ini sejalan dengan penelitian Sigurs $\mathrm{dkk}^{16}$ yang menyatakan bahwa infeksi Respiratory Syncitial Virus (RSV) menunjukkan rata-rata $40 \%$ akan berlanjut menjadi mengi atau asma pada masa anak. Pajanan asap rokok dinilai hanya pada lingkungan di dalam rumah, sedangkan pajanan di luar rumah sulit dihindari. Hal tersebut dapat menyebabkan tidak terdapat perbedaan antara kedua kelompok pada penelitian ini.

Beberapa penelitian mengatakan infeksi saluran pernapasan dan pajanan asap rokok dapat berpengaruh pada kadar vitamin C plasma. Hasil analisis tidak menunjukkan perbedaan antara pajanan asap rokok dan infeksi saluran pernapasan pada kelompok anak serangan asma maupun tidak serangan.

Alergi makanan juga tidak menunjukkan perbedaan antara kelompok anak asma dalam serangan dan tidak serangan. Hasil tersebut kemungkinan dapat dipengaruhi oleh ketidaktahuan orangtua sehingga tidak diketahui dengan pasti riwayat alergi makanan pada pasien penelitian ini. Selain itu, secara teori dikatakan bahwa asma merupakan manifestasi yang jarang terjadi pada alergi makanan. ${ }^{17}$

Pajanan terhadap alergen hirupan dalam rumah seperti alergen hewan peliharaan, alergen tungau debu rumah, juga tidak menunjukkan perbedaan antara kelompok anak asma dalam sernagan dan tidak serangan. Beberapa penelitian memang masih kontrovensi, Lau $\mathrm{dkk}^{18}$ mengatakan tidak terdapat hubungan antara jumlah tungau debu rumah dan asma pada anak. Gold $\mathrm{dkk}^{19}$ mengatakan bahwa untuk memastikan peranan tungau debu rumah dan alergen hirupan dalam rumah lainnya perlu dilakukan pengukuran partikel dan juga mendeteksi kadarnya pada udara. Pengukuran alergen juga dapat dilakukan dengan tes alergi uji gores kulit, tetapi tidak dilakukan pada penelitian ini.

\section{Kesimpulan}

Kadar vitamin C plasma rendah tidak berhubungan dengan serangan asma pada anak. Infeksi saluran pernapasan dapat merupakan faktor risiko serangan asma anak. Berdasarkan hasil tersebut vitamin C 
tidak perlu diberikan sebagai terapi pada anak penderita asma. Penderita asma dan keluarga dapat melakukan pencegahan serangan asma dengan cara menjaga kesehatan agar tidak terkena infeksi saluran pernapasan.

\section{Daftar pustaka}

1. Kartasasmita CB. Epidemiologi asma anak. Buku ajar respirologi anak. Jakarta: IDAI; 2008.h.71-5.

2. Global initiative for Asthma (GINA). Global strategy for asthma management and prevention. GINA Workshop Report;2011.h. 2-14.

3. Pusponegoro HD, Hadinegoro SRS, Firmanda D, Tridjaja BAAP, Pudjiadi, AH, Kosim MS, dkk. Asma bronchial tatalaksana jangka panjang. Jakarta: IDAI; 2004.h.341.

4. Khan RIH, Muller DC, Wise. Serum vitamin levels and the risk of asthma in children. Am J Epidemiol 2003;159:351-7.

5. Misso N, Thompson PJ, dkk. Oxidative stress and antioxidant deficiencies in asthma: potencial modification by diet. Redox Report 2005;10:247-53.

6. Britton JR, Pavord ID, Richards KA, Knox AJ, Wisniewski AF, Leweis SA, dkk. Dietary ontioxidant vitamin intake and lung function in general population. Am J Resp Crit Care Med 1995;151:1383-7.

7. Grievink L, Waart FG, Schouten EG, Kok FJ. Serum caretinoids, alpha-tocopherol, and lung function among Dutch elderly. Am J Resp Crit Care Med 2000;161:7905.

8. Hijazi N, Abalkhail, Bahaa, Seaton A. Diet and childhood asthma in a society in transition: a study in urban and rural Saudi Arabia. Thorax 2000;55:775-9.
9. Powell CV, Nash AA, Powers HJ. Antioxidant status in asthma. Pediatr Pulmonol 1994; 18:34-8.

10. Shidfar F, Baghai N, Keshavarz A, Ameri A, Shidfar S. Comparison of plasma and leukocyte vitamin C status between asthmatic and healthy subjects. East Mediterranean Health J 2005;11:87-95.

11. Hatch GE. Asthma, Inhaled oxidants, and dietary oxidants, Am J Clin Nutr 1995;61:625-30.

12. Hastono SP. Basic data analysis for health research training. Jakarta: FKM UI; 2006.

13. Aldington $S$ And Beasley R. Definition and diagnosis of asthma. Dalam: An atlas of investigation and management asthma, Jhonston S.L, penyunting. London: Oxford; 2007.h.1-10

14. McKeever TM, Britton J. Diet and Asthma. Am J Res and Crit Care Med 2004;170:234-8.

15. Al-Abdulla NO, Al Naama LM, Hassan MK. Antioxidant status in acute asthmatic attack in children. JPMA 2010;60:1023-7.

16. Sigurs N, Bjarnason R, Sigurbergsson F, Kjellman B. Respiratory syncytial virus bronchiolitis in infancy is an important risk factor for asthma and allergy at age 7. Am J Respir Crit Care Med 2000;161:1501-7.

17. Kewalramani A and Bollinger ME. The impact of food allergy on asthma. J Asthma and Allergy 2010;3:6574.

18. Lau S, Illi S, Platt-Mills TA, Riposo D, Nickel R, Gruber C, dkk. Longitudinal Study on relationship between cat allergen and endotoxin exsposure, sensitization, cat specific IgG and development of asthma in childhoodreport of the German Multicentre Allergy Study (MAS 90). Allergy 2005;60:766-73.

19. Gold DR. Environtmental tobacco smoke, indoor allergens, and childhood asthma. Environ Health Perspect 2000;4:643-51. 